\title{
Pleural lipoma: when to intervene
}

\author{
Bilal Malik 다, ${ }^{1}$ Basel Abdelazeem 다, ${ }^{1}$ Abhijeet Ghatol (1) ${ }^{2}$
}

${ }^{1}$ Internal Medicine, McLaren Health Care Corp/ Michigan State University (MSU), Flint, Michigan, USA

${ }^{2}$ Pulmonary and Critical Care Medicine, McLaren Health Care Corp/ Michigan State University (MSU), Flint, Michigan, USA

\section{Correspondence to}

Dr Bilal Malik;

Bilal.Malik@mclaren.org

Accepted 5 April 2021

\section{DESCRIPTION}

A 49-year-old woman with a medical history of type 2 diabetes mellitus, hypertension, obstructive sleep apnoea and morbid obesity presented to the pulmonary clinic with chest discomfort on her right side. On physical examination, the patient was in no acute distress, had air entry bilaterally with equal chest expansion and did not have any wheezing or added sounds on auscultation. She previously had chest X-rays done in 2012, 2018 and 2019, which had demonstrated a lesion in the right anterior middle lobe (figure 1 ). The mass had slightly increased in size from 2012 to $2018(4.3-4.6 \mathrm{~cm}$, respectively), but remained stable thereafter. Repeat imaging with CT scan and chest X-ray in 2021 demonstrated that the mass had remained stable at $4.6 \mathrm{~cm}$ in the craniocaudal dimension (figure 1 ) and demonstrated benign features on imaging including a homogeneous constitution, Hounsfield units consistent with fat density, smooth borders and no invasion of surrounding structures (figure 2). ${ }^{12}$ This case highlights the importance of key imaging features in differentiating benign and malignant lesions in such cases.

The potential size of lipomas leads to an extensive workup with unnecessary and invasive procedures by providers that lack awareness of such entities. Reports have been documented with lesions reaching $25 \mathrm{~cm}$ in size ${ }^{3}$ and necessitating thoracic surgery for removal secondary to mass effect/ compression of surrounding anatomy. Our patient was followed with serial imaging studies, without biopsy, of a moderately sized, fatty mass on her CT imaging with no significant effect on her functional status. She does not have limitations in her daily activity. Additionally, her pulmonary function

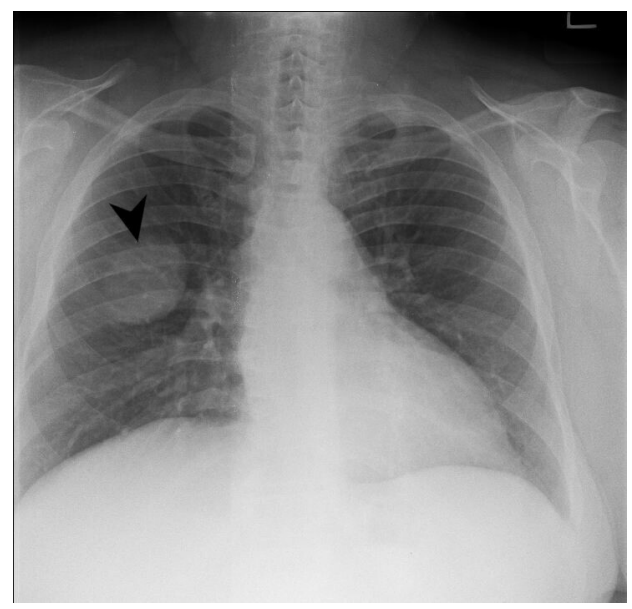

Figure 1 Chest $X$-ray demonstrating a $4.6 \mathrm{~cm}$ (craniocaudal dimension) mass in the right middle lung field (black arrowhead).

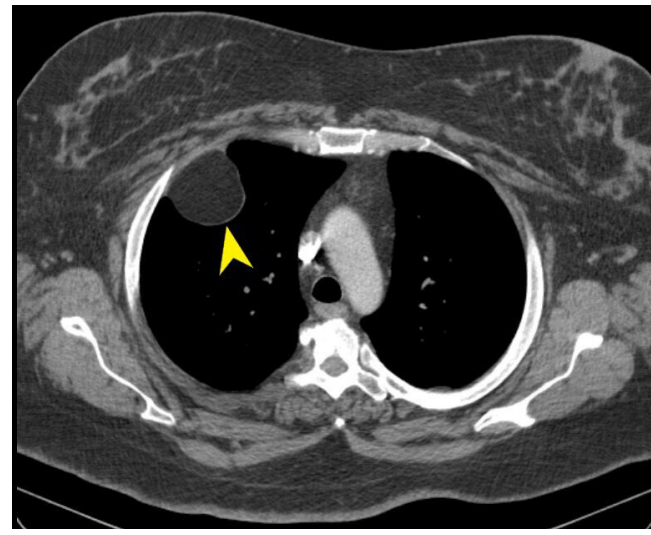

Figure 2 Transverse section of CT chest-yellow arrowhead demonstrates a well-defined lesion in the anterior right middle lung field, originating from the pleura. Note the homogeneous appearance and welldefined borders with no invasion of adjacent structures.

testing was unremarkable, including lung volumes and gas diffusion capacity. In patients with significant compression or mass effect (eg, causing cardiovascular compromise or dyspnoea) and reduced pulmonary function, surgical intervention may be appropriate. ${ }^{13}$

Differential diagnosis included liposarcoma, which would require further workup for diagnosis with histopathology and intervention as a malignant entity. ${ }^{12}$ The key differentiating feature would be a

\section{Patient's perspective}

Initially, it was concerning finding such a large mass on chest X-ray. I was relieved when I found out that my doctors did not suspect cancer, and that I would not have to undergo any procedures unless it was necessary later. I was informed regarding the rarity of my case and am very happy with the care I have received.

Learning points

- Consider pleural lipoma as a differential diagnosis in a chest mass on imaging.

- Identify features on imaging that may lead you to observe a chest mass/lesion with serial imaging as opposed to perform invasive workup/procedures.

- Important considerations of identifying alarm features in a suspected liposarcoma and when to consider invasive biopsy and/or surgical intervention. 
heterogeneous constitution or invasion of neighbouring anatomical structures prompting further workup. Importantly, CT or MRI demonstrates contrast enhancement in areas of irregular appearing soft tissue. Positron emission tomography also proves valuable in differentiating lipomas and liposarcomas when the diagnosis is unclear. ${ }^{1}$

Contributors $\mathrm{BM}$ and $\mathrm{BA}$ contributed equally in the writing and editing of the manuscript. AG supervised the project and made significant changes to the final manuscript. All authors agreed upon the finalised manuscript to be published. All authors agreed to be accountable for all aspects of the work in ensuring that questions related to the accuracy or integrity of any part of the work are appropriately investigated and resolved.

Funding The authors have not declared a specific grant for this research from any funding agency in the public, commercial or not-for-profit sectors.
Competing interests None declared.

Patient consent for publication Obtained.

Provenance and peer review Not commissioned; externally peer reviewed.

\section{ORCID iDs}

Bilal Malik http://orcid.org/0000-0001-8762-7321

Basel Abdelazeem http://orcid.org/0000-0002-2919-6196

Abhijeet Ghatol http://orcid.org/0000-0002-8516-4471

\section{REFERENCES}

1 Molinari F, Bankier AA, Eisenberg RL. Fat-containing lesions in adult thoracic imaging. AJR Am J Roentgenol 2011;197:W795-813.

2 Suut S, Al-Ani Z, Allen C, et al. Pictorial essay of radiological features of benign intrathoracic masses. Ann Thorac Med 2015;10:231.

3 Aldahmashi M, Elmadawy A, Mahdy M, et al. The largest reported intrathoracic lipoma: a case report and current perspectives review. J Cardiothorac Surg 2019;14:1-5.

Copyright 2021 BMJ Publishing Group. All rights reserved. For permission to reuse any of this content visit

https://www.bmi.com/company/products-services/rights-and-licensing/permissions/

BMJ Case Report Fellows may re-use this article for personal use and teaching without any further permission.

Become a Fellow of BMJ Case Reports today and you can:

- Submit as many cases as you like

Enjoy fast sympathetic peer review and rapid publication of accepted articles

Access all the published articles

Re-use any of the published material for personal use and teaching without further permission

Customer Service

If you have any further queries about your subscription, please contact our customer services team on +44 (0) 2071111105 or via email at support@bmj.com.

Visit casereports.bmj.com for more articles like this and to become a Fellow 